DOI: $10.17516 / 1997-1370-0632$

УДК 93

\title{
The Dynasty of the Yeniseysk Merchants Kobychevs: Formation, Entrepreneurship, Participation in Public Life
}

\author{
Evgeniya V. Komleva* \\ Institute of History of the Siberian Branch of the RAS \\ Novosibirsk, Russian Federation
}

Received 28.08.2019, received in revised form 04.06.2020, accepted 09.07.2020

\begin{abstract}
The article discusses the story of one of the most wealthy and influential merchant dynasties of Yeniseisk in the $19^{\text {th }}$ century - the Kobychevs. It gives the biographical data (including previously unknown) about the representatives of different generations of this family and characterizes their economic activities, public service, lifestyle. The reconstruction of the Kobychevs' life path allows us to reveal the features inherent to the development of the Siberian merchant class in general and concerning the conditions and ways of initial accumulation of capital, the spheres of its further circulation, conflicts and interaction with the regional administration, the influence of merchants on the urban environment. The analysis of biographical information about the Kobychevs contained in periodicals and works of their contemporaries, emphasizes the important position of the merchant class in the structure of the Siberian urban society and the significant contribution of merchants to the economy, public and cultural life of the region.
\end{abstract}

Keywords: Siberian merchantry, Yeniseisk, the Kobychevs, biography, economic activities, public services, lifestyle.

Research area: history, culturology.

Citation: Komleva, E.V. (2020). The dynasty of the Yeniseysk merchants Kobychevs: formation, entrepreneurship, participation in public life. J. Sib. Fed. Univ. Humanit. Soc. Sci., 13(7), 1144-1152. DOI: $10.17516 / 1997-1370-0632$.

\footnotetext{
(C) Siberian Federal University. All rights reserved

* Corresponding author E-mail address: feodal@history.nsc.ru ORCID: 0000-0002-6975-3516
} 
There are many well-known surnames among the Yeniseisk merchants of $18^{\text {th }}-$ early $20^{\text {th }}$ century. The Kytmanovs, Vostrotins, Balandins - representatives of different generations of these families left a deep mark in the history of Siberia. However, besides them, the Yenisei merchants included other families, who may not have brightly shown themselves, but there were no less worthy people who did a lot for the development of their hometown. The resurrection of their names and facts of biographies is relevant not only as a contribution to local history research, but also in the light of the interest in the life of the so-called "background" person existing in domestic and foreign historiography today, that is, the one who "at least stands out from the crowd, but at the same time, according to the objective results of their activities, or in the perception of contemporaries and / or descendants "does not reach" the scale of "history maker" and "arbiter of fate", "and attention to whom allows us to "investigate the intersection of personal and mass, group stereotypes and individual consciousness, internal motive of behavior and external factors, human and social essence of the era" (Mininkov, Korenevsky, Ivanesco, 2010: 24-25).

This article will focus on the wealthy and once influential dynasty of the Yenisei merchants Kobychevs, brief essays about which are included in the scientific and reference publications of recent years (Komleva, 2009: 96; Komleva, 2012: 317; Bykonya, Komleva, Pogrebnyak, 2012: 164- 165). A detailed reconstruction of the history of this family, which has several generations, is possible due to the occurrence of references to its members in paperwork, materials of the periodical press of the second half of the $19^{\text {th }}$ - early $20^{\text {th }}$ centuries, publications of the authors of the $19^{\text {th }}$ century and modern researchers. One of the most important sources is the famous "Brief Chronicle" by A.I. Kytmanov, the author of which, by the way, when preparing his work, repeatedly consulted the direct descendant of the Kobychevs. This fact underlines the position of the latter among local society, the degree of their awareness and participation in the development of the city. Obviously, the Kobychevs compiled something like a family archive: A.I. Kytmanov refers not only to oral comments (Kytmanov, 2016: 244, 284, 296-297, 299, 301, 306, 319,383 ), but also to a number of documents submitted to him - "A.A. Kobychev's papers" (Kytmanov, 2016: 128, 211, 217, 223, 241). The presence of such a collection testifies not only to the literacy of the Kobychevs, but to a sufficiently high cultural and educational level, their attentive attitude to the fate of both their family and their small homeland.

The Kobychevs appeared in Siberia quite late - in the second half of the $18^{\text {th }}$ century (at least, the owners of this surname do not appear among the large service population of the region at the end of the $16^{\text {th }}$ - beginning of the $18^{\text {th }}$ centuries ${ }^{1}$; they were not among the residents of the Yeniseisk of the $18^{\text {th }}$ century (Bulankov and Shumov, 1999: 110-113)). According to G.F. Bykonya, "quite numerous rural townspeople Kobychevs" who lived in the 1790s in the Kazachinsky volost of the Yenisei Uyezd and engaged in tillage and "various works" could become the ancestors of the merchant dynasty (Bykonya, Komleva, Pogrebnyak, 2012: 164).

For the first time, the Kobychevs declared capital and joined the Yeniseisk merchants in the 1810s: it is known that at the end of 1815, Grigorii Prokop'evich Kobychev (died in 1817), who was a member of the $3^{\text {rd }}$ guild, petitioned the Tobolsk provincial government for temporary admission to the Turukhansk merchants, in which he reported that he traded there by proxy from the Yenisei merchants of the $2^{\text {nd }}$ guild (Bulankov, Shumov, 1999: 67). It was a usual beginning of the path of many Siberian merchants who subsequently became rich and famous. The fur trade, which brought good profits, allowed G.P. Kobychev to transfer a solid capital to his son Aleksandr. It is interesting that before his death, Grigorii Prokop'evich bequeathed, "so that heirs would not start contention or petition and even litigation in court" (Kytmanov, 2016: 319). In 1816, a certain Petr Kobychev was also mentioned, who served as a councillor in the Yenisei City Council. The latter circumstance with a high degree of prob-

The file cabinet of service people from the archive of D.Ya. Rezun: Manuscript. Institute of History, SB RAS. 
ability gives reason to assume that he, too, was one of the local merchants; as for his family ties with Grigorii Prokop'evich, no indications of this have been preserved (Kytmanov, 2016: 184).

The representative of the second generation of the merchant dynasty Alexander G. Kobychev (1787-1839) ${ }^{2}$ became one of the largest Yenisei merchants of the second quarter of the $19^{\text {th }}$ century. The basis of his well-being, like his father, was the purchase of fur in the Turukhansk Territory and its subsequent resale; he was connected with the Turukhansk Territory, Kyakhta, Moscow (Kytmanov, 2016: 217). In the list of merchants of Yeniseisk for 1827, it was stated that he was the only person to declare capital according to the $1^{\text {st }}$ guild, and was engaged in trade "with Russian, Chinese and fur goods in bulk and at retail in Kyakhta and within the empire." ${ }^{3}$ In general, the 1820 s can be called the time of the greatest flowering of the Kobychev family business. The first Yenisei Civil Governor A.P. Stepanov, characterizing the merchants of Yeniseisk, along with Z.Kh. Tolstoy and M.F. Khoroshikh highlighted A.G. Kobychev, noting that "all other trading houses in this city fell", and the "community" of Yenisei merchants "is nothing but the ruins of a capital building, the vaults of which are supported by two or three pillars" (Stepanov, 1835: 157, 255). Subsequently, the circumstances for Aleksandr Grigor'evich were no longer so successful: in 1830 he moved to the $3^{\text {rd }}$ guild, in 1831 he again declared capital according to the $1^{\text {st }}$ guild (in the list of merchants for 1838 his last name was listed under the first number ${ }^{4}$ ) but before his death, in 1839, he again found himself in the lower stratum of the merchants (Kytmanov, 2016: 217).

Speaking about the methods practiced by wealthy Yenisei merchants, V.V. Bulankov writes that they considered the Turukhansk Territory to be their monopoly possession (Bulankov, Shumov, 1999: 87). A.I. Kytmanov cites

\footnotetext{
2 In the "Yenisei Merchants in Persons" it is indicated that he was born in 1790 (Bykonya, Komleva, Pogrebnyak, 2012: 164), while the inscription on the gravestone, seen by A.I. Kytmanov, allows clarifying this date and attributing it to an earlier time (Kytmanov, 2016: 243).

3 RSIA. F. 18, op. 4, d. 336, 1. 153.

4 RSIA. F. 18 , op. 4, d. 589 , 1. 168.
}

an incident that occurred in 1829 when several Yenisei merchants, including A.G. Kobychev, considering the Angara, as well as the lower Yenisei, to be their legal patrimony, jointly opposed a certain Kiren peasant Vladimirov, who allegedly "illegally traded near the Angara and oppressed the merchants." The case was resolved in favour of the innocent Vladimirov (Kytmnov, 2016: 220).

The influence A.G. Kobychev was also expressed in the fact that he repeatedly performed various public services of his choice: he served as a burgomaster in the city magistrate, since 1825 he was a candidate (i.e. assistant, deputy) of the mayor, merchant Stepan Kolmakov, and in 1828 he became the Yenisei mayor. Since S. Kolmakov often went away on business to the Turukhansk Territory, and in addition, "he was a sick person then" (Kytmanov, 2016: 211), A.G. Kobychev, in fact, had to fulfil the duties of the mayor for two consecutive three years. Service in the city government was associated with considerable financial costs: Aleksandr Grigor'evich, being the head of the city, donated to the stone barracks for the disabled team and to the extension of the second stone floor above the city council. In addition, at his own expense, he built a warm chapel to the Assumption Cemetery Church, founded in 1826 by Irkutsk bishop Michael who visited Yeniseisk and consecrated the chapel on November 23, 1827 in the name of St. Innocent of Irkutsk (Shanin, 2011: 311).

For many years, the Kobychev family archive kept certificates issued to Aleksandr Grigor'evich by the inhabitants of Yeniseisk at the end of his public services. In one of them, in a somewhat confused language (which, incidentally, is fully consistent with the original text of the manuscript ${ }^{5}$ ), it was said, "He was servicing good, which contributed to the common wealth; he was efficient, and aspired to make money in all ways. Besides, he always had in mind to build what was necessary for the city, and sometimes he built it at his own

\footnotetext{
Kytmanov A.I. (2016). Kratkaia letopis' Eniseiskogo uezda i Turukhanskogo kraia Eniseiskoi gubernii. 1594-1893 god [Brief Chronicle of the Yenisei Uyezd and the Turukhansk Territory of the Yenisei Province. 1594-1893]. Krasnoyarsk. KRMLL. F. 341, d. 7886/229, 1. 311.
} 
expense, being a philanthrope. In another certificate, it was said that he "particularly showed jealousy that was worthy of respect for his goodwill, at first using some part of the capital and material of the Yenisei merchant Matvey Khoroshikh at his own wish, and then sacrificing his own capital, Mr. Kobychev built the stone building's second storey above the Duma and the stone barracks for the local disabled team through volunteers, contributing to the benefit of society, with the approval of the higher authorities, and without asking the society to participate in this" (Kytmanov, 2016: 211, 217).

Being an authoritative and independent person, A.G. Kobychev several times faced with the local administration. One of the conflicts occurred in 1837, when the Yenisei city mayor demanded to stop the construction of the stone wing at A.G. Kobychev's house, which, as it turned out, was not agreed with the provincial construction commission, however, "40 workers engaged in "impermissible work" resisted and continued to work." Clashes with the authorities and mutual distrust led to the fact that before his death, Aleksandr Grigor'evich "bequeathed that his heirs would not depend on any public place or on any bosses" (Kytmanov, 2016: 241, 319).

Almost nothing is known about the personal life of A.G. Kobychev. Only references to the fact that he was married to the daughter of Archpriest Ushakov have survived. Despite her undoubtedly educated parent, she, like her sister, was illiterate, recalled by merchant I.I. Dement'ev (Kytmanov, 2016: 224). Female education in Siberia began to develop closer to the middle of the $19^{\text {th }}$ century. A son Alexander and two daughters were brought up in the Kobychev family, one of whom, Natalia (born in1822), married another prominent Yenisei merchant Nikandr Fedorovich Dement'ev' ${ }^{6}$.

The $3^{\text {rd }}$ generation of the merchant dynasty of the Kobychevs is represented by the only son of Aleksandr Grigor'evich - Aleksandr Aleksandrovich (1821-1856). Like many other merchant offspring of the first half of the $19^{\text {th }}$ century, he received home education. At the same time, contemporaries noted that he was a developed and well-read man, composed poems

\footnotetext{
6 SAKK. F. 160, op. 1, d. 257, 1. 1 ob. -2 .
}

in which, in particular, described his trips to the North, and which, unfortunately, were subsequently lost. A.I. Kytmanov calls A.A. Kobychev the most interesting representative of the Yenisei merchants of the middle of the $19^{\text {th }}$ century. In his "beautiful house" there were parties at which "a large diverse society" gathered: merchants, gold miners, officials, various visitors. The guests had fun, played cards, billiards, smoked tobacco "from the owner's floor-long pipes", and once "during one ball, gold miners Stepan Solovyov and Narkiz Zotov drank champagne from the white satin shoe of beautiful V." (Kytmanov, 2016: 297). The Kobychevs became one of the first residents of the city, who in the late 1840 s, acquired the piano (Barkova, 1887: 179).

However, Aleksandr Aleksandrovich spent time not only in conversations and dances. Left at the age of eighteen without a father, he was forced to plunge into the family business, repeatedly travelled to Kyakhta, Nizhny Novgorod, Irbit, Moscow and, of course, to the Turukhansk Territory. Business developed successfully, and in 1842 he was the first in Yeniseisk to be awarded the title of hereditary honorary citizen (Kytmanov, 2016: 284). This right was possessed by merchants who spent twenty years in a row in the $1^{\text {st }}$ guild without being brought to court during this time ${ }^{7}$. And although we saw that A.G. Kobychev did not always declare capital on the $1^{\text {st }}$ guild, occasionally appearing even in the $3^{\text {rd }}$ one, probably, in practice, small deviations from the conditions specified in the decree were possible. This further emphasizes the weight of the Kobychevs in local society and their undoubted authority in the eyes of the government.

Aleksandr Aleksandrovich is the author of a very interesting document that is a project for the development of the Yenisei North - a vast region with a low population density and difficult living conditions, which caused constant concern of the authorities. The essence of the proposals of A.A. Kobychev, put forward in 1853, is described in detail in the book of M.F. Krivoshein, who worked as a doctor for several years in the Yenisei district. The

\footnotetext{
CCL LRE (1833). Collection 2. SPb. Vol. 7 (5284), 193195.
} 
merchant offered to give him these lands (that is, the right to trade with the local population, export "all outcomes of fishing and animal industries", develop minerals here) into a monopoly for 25 years, pledging to pay taxes and tributes for the local population in exchange, to provide residents with bread, to maintain a physician and a Cossack team at his own expense (Krivoshein, 1865: 14-17). This story is also cited in the "Eastern Review" for 1896, an anonymous correspondent of which, based on information reported by M.F. Krivoshein, like the latter, calls the merchant Kobachev the author of the project "On Promoting the Welfare of the Turukhansk Territory Residents," and writes that the latter "was a wonderful person for his time." He knew well the needs of the region, and his project almost received approval. After his death, many other merchants, encouraged by his success, also submitted projects of different types of monopoly ownership of the region, but times have changed, and they did not arouse sympathy." "By "some individuals" he meant the entrepreneur Lavrovsky, who also "submitted a project on taking the Turukhansk Territory for rent" (Krivoshein, 1865: 14). This plot, of course, is not ignored by A.I. Kytmanov's "Brief Chronicle" (Kytmanov, 2016: 325).

Having become independent, A.A. Kobychev, still being a very young man, already "enjoyed great respect in the local community." In 1846, he was elected the Yenisei mayor for three years - he was only 25 years old, which was a rare case for such an age to take up such a responsible position. It is important to say, Aleksandr Aleksandrovich justified the trust shown to him by fellow citizens. During the service, he set up exchange shops at his own expense and bought good furniture for the City Duma, for which he spent 2 thousand roubles in silver; during the great flood of 1848, he distributed bread to people in need, and this helped to lower prices (while "the gold miners Solovyovs travelled around the flooded city with music and singing"). Remembering and appreciating all this, the society awarded

\footnotetext{
8 Turukhanskii krai [The Turukhansk Territory] (1896). In Vostochnoe obozrenie [Eastern Review], 116 (dated October, 2), 3 .
}

AA Kobychev a commendation sheet "for his striving for the benefit of the public, exemplary care for increasing city incomes", and in 1852 the residents of Yeniseisk again elected him to the same post (Kytmanov, 2016: 284, 293, 319).

But without even being in the service, Aleksandr Aleksandrovich continued to engage in charity work, showing himself as a generous donor for the needs of the Orthodox Church: he built a second chapel to the Assumption Church, consecrated on August 25, 1843 in the name of the Holy Prince Alexander Nevsky (Shanin, 2011: 311 ); raised money for casting the largest bell in the city weighing 500 pounds for the Resurrection Church, which in 1850, "with a huge gathering of people" was raised to the bell tower. For all his deeds A.A. Kobychev was awarded a gold medal with the inscription "For zeal." The good deeds of Aleksandr Aleksandrovich made the Yeniseisk citizens deeply regret his death in 1856, and "many" people came to see him on his final journey (Kytmanov, 2016: 308, 341).

Not only the city, but also the higher authorities had every reason to distinguish Aleksandr Aleksandrovich from local society. It is no accident that the Yenisei civil governor V.K. Padalka "always stayed" in his house, as well as the Governor-General of Eastern Siberia N.N. Muravyov (Kytmanov, 2016: 297, 308 ) in 1850 . V.K. Padalka, an honest, fair person and an energetic administrator (Berdnikov, 1995: 55-56, 60), was generally "on great friendly terms" with A.A. Kobychev (Kytmanov, 2016: 297). At the same time, it is characteristic that, like his father, A.A. Kobychev was in conflict with the city authorities. A.I. Kytmanov reports that he was in "bad relations" with the Yenisei city mayor Vakhrushev, who "even after the death of Kobychev [...] picked holes in the permission to bury him in the fence of the convent". Following Aleksandr Grigor'evich, A.A. Kobychev wanted his heirs not to depend on the authorities (Kytmanov, 2016: 319).

The last known representative of the dynasty, but, apparently, no longer among the merchants, was Aleksandr Aleksandrovich (born in 1843) - a complete namesake of his father, who, like all his ancestors-merchants, 
left a noticeable mark in the history of Yeniseisk. He probably tried for some time to continue the family business - most likely, in 1859 he was one of the main smelters of supplies in Yeniseisk, including bread delivered from Minusinsk and Krasnoyarsk districts ("Matonin, Tokarev, Funtosov, Gryaznov Danilov, Zaitsev, Kobychev, Efimov") (Kytmanov, 2016: 368). In the lists of capital owners of 1858, 1862 and later, he was never mentioned ${ }^{9}$; Obviously, information about him, as a hereditary honorary citizen, was entered into the town philistine book. The departure from broad commercial activity did not prevent him from remaining one of the most prominent and authoritative members of the Yenisei society. It was he who kept the family archive and advised A.I. Kytmanov, the author of "Brief Chronicle." In the 1860-1890s, he actively supported the Public Library at the Yenisei Museum of Local Lore: in particular, he presented it books on the gold industry, as well as printed Reports and News of the Russian Geographical Society. His merits were mentioned in a note by N.V. Skornyakov, published in the "Yenisei Provincial Gazette", "... I consider it my duty to bring gratitude to the Mr A.I. Dudkinsky, A.A. Kobychev, A.S. Popov, E.L. Polyakov and S.A. Moiseev for books and magazines presented for the public library. A librarian of the Yenisei Public Library Nikita Vissarionov Skornyakov. October 29, 1864."'10 In 1909 A.A. Kobychev was mentioned as an honorary guardian of the $5^{\text {th }}$ Women's Parish School in Yeniseisk (Bykonya, Komleva, Pogrebnyak, 2012: 164).

So far, no information has been found about the family of Aleksandr Aleksandrovich. Perhaps, Evgenia Kobycheva, mentioned in the diary of the famous Krasnoyarsk archpriest Vasily Kasyanov, was in some relationship with him: on April 22, 1870, he wrote that he had sent her a letter to Jerusalem (Kasyanov, 2012: 43). Pilgrimage trips to the Holy Land were not uncommon: many wealthy people went on a long journey and even publicly announced their intentions. Thus, for example, in March 1867 , an ad was posted in the press stating that

\footnotetext{
9 SAKK. F. 160 , op. 1, d. 257, 1. 1 ob - 20; op. 3, d. 670, 1. 1 ob $-34 \mathrm{ob}$.

10 YPG (1864), 46. 205.
}

"Yenisei merchant Yakov Alekseev Panfilov, intending to go with his wife Stepanida Ivanovna to Jerusalem to worship St. places, what he was happy to inform the public about." 11

In the $19^{\text {th }}$ century, there were other people with the surname Kobychev among the Yenisei merchants, whose family ties with the main line of the merchant dynasty were not precisely established. The most famous among them is Kozma Kobychev, who in 1822 was listed as the only Yenisei merchant of the $1^{\text {st }}$ guild. The aforementioned words of the founder of the merchant dynasty Grigorii Prokop'evich Kobychev about the inadmissibility of conflicts between heirs give reason to believe that Kozma could well be one of them, for example, the eldest son of G.P. Kobychev. Like Alexander Grigor'evich, Kozma was engaged in Kyakhta $\operatorname{trade}^{12}$, however, apparently, far from being so successful - his sons Grigorii Kozmich (born in 1819) and Nikolai Kozmich (born in 1820 - mid-1860s) traded various goods and in the second half of the 1830 s - early 1860 s continued to declare capital only on the $3^{\text {rd }}$ guild: in 1835 and 1838 Grigorii did $^{13}$, and since 1845 Nicholas did, who managed to return to the merchants again from the middle class ${ }^{14}$. The latter owned a house, which during a severe flood in May 1848 came close to water (Kytmanov, 2016: 292), and in the 1860s in the Yenisei city court examined a number of cases in which his name appeared. In 1863, a retired provincial secretary S.I. Tetskov, a trustee of the Tyumen $1^{\text {st }}$ guild merchant A.G. Glaskov, collected debt from Nikolai Kozmich "for three bills of 1385 roubles." ${ }^{\prime 5}$. Next year, N.K. Kobychev was in the company of merchants (the Minusinsk merchant son Averyan Matonin, the Kolyvan merchant son Fedor Sorokin and the Yenisei merchant Aleksandr Kytmanov), who demanded A.S. Kalinin-Shushlyaev to return 22386 roubles. $671 / 2 \mathrm{k}^{16}$. And yet N.K. Kobychev failed to improve his financial situation: in 1867 his widow Aglaida Ivanovna Kobycheva

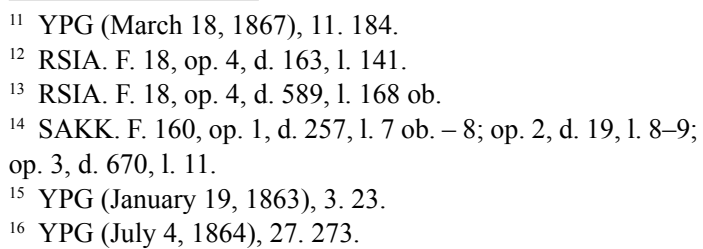


had to deal with the claim of S.I. Tetskov to recover 900 roubles in silver ${ }^{17}$.

The sources also mention: the $3^{\text {rd }}$ guild merchant Dmitry Aleksandrovich Kobychev who sold small goods in $1827,{ }^{18}$ the $2^{\text {nd }}$ guild manufactory merchant Aleksei Ivanovich Kobychev, who was a member of the account committee of the Yenisei Public Bank (born in 1855), the councillor of the local city council Mikhail Stepanovich Kobychev, a candidate (assistant, deputy) of the city judge M.D. Kobychev (Kytmanov, 2012: 292, 460, 480, 527, 577, 592), a contributor to the Public Bank Savva Kobychev, whose successor demanded payment of interest for several years ${ }^{19}$. In 1912, the owners of real estate Mikhail Stepanovich and Faddey Alekseevich Kobychevs who paid apartment tax were mentioned in the list of electors for the $4^{\text {th }}$ State Duma of Yeniseisk ${ }^{20}$.

The name of M.D. Kobychev was associated with a case of refusal to perform the service of choice. This was not something exceptional: the services were burdensome, they required time and effort, and sometimes private means, and often the citizens, if given any opportunity, sought to avoid them. And yet the case cited by A.I. Kytmanov is very indicative from the point of view of the methods resorted to by people who wanted to evade service. According to the author of the "Brief Chronicle", in 1884 I.A. Popov was elected as a judge to the Yenisei City Court, while N.V. Skornyakov was elected as "a candidate for the judge position", who in a written request addressed to the governor "stated that he considers the service in this old obsolete institution to be inadequate to his convictions and cannot take an oath against

\footnotetext{
17 YPG (March 11, 1867), 10. 150-151.

${ }_{18}$ RSIA. F. 18, op. 4, d. 336, 1. 154.

19 YPG (1885), 44 (November 2). 9; 1(886), 18 (May 3). 8; (1887), 2 (May 30). 6.

20 YPG. 1912. Appendix to No. 100 (August 1).
}

conscience". Then A.M. Borodkin was chosen instead of him, "but he also refused, presenting a certificate of illness from the doctor Zhilin," then the choice turned next to Matonin, but he referred to the fact that "he had just finished his service as a church warden." Finally, it came to M.D. Kobychev, "but this choice was unsuccessful: he presented the testimony of a doctor who certified that the painful manifestations of Kobychev probably depend on the constant immoderate consumption of alcoholic beverages." In the end, A. Borodkin agreed to take the position, having learned "about the upcoming abolition of the city court" (Kytmanov, 2012: 592).

Thus, the history of the Yenisei merchants Kobychevs, traced over four generations, emphasizes the important role of merchants in the life of the Siberian city, particularly they participated in the formation and development of its economy and public life, determined the level of cultural needs, interests and value guidelines of citizens. Having managed to make up capital in the fur trade, the Kobychevs entered the upper layers of the merchants of Yeniseysk, repeatedly performed public services in the city government, donated to the needs of the Orthodox Church, to improve the city, defended their opinions, not being afraid of clashes with the authorities. The dying of the dynasty in the second half of the $19^{\text {th }}$ century can probably be partly explained by the inability to adapt to the challenges of the post-reform period, when the decline in the fur trade had to be compensated for by other areas of activity. And yet, in a relatively short period of their heyday, the Kobychevs managed to contribute to the development of their small homeland, showed themselves as initiative individuals, ready to come up with bold proposals for the economic development of the inaccessible northern territories of Siberia, whose names are worthy of the memory of their descendants. 


\section{References}

Barkova, A.I. (1887). Vospominaniia o sibirskoi zolotopromyshlennosti [Memories of the Siberian gold mining]. In Sibirskii sbornik [Siberian coll2ection]. St. Petersburg, 168-186.

Berdnikov, L.P. (1995). Vsia krasnoiarskaia vlast': Ocherki istorii mestnogo upravleniia i samoupravleniia (1822-1916). Fakty, sobytiia, liudi [All Krasnoyarsk authorities: Essays on the history of local government and self-government (1822-1916). Facts, events, people]. Krasnoyarsk, Publishing House, 320 p.

Bulankov, V.V., Shumov, K.Yu. (1999). Eniseisk. Ocherki po istorii razvitiia i zastroiki goroda [Yeniseisk. Essays on the history of the development and building of the city]. Krasnoyarsk, Publishing House, $216 \mathrm{p}$.

Bykonya, G.F., Komleva, E.V., Pogrebnyak, A.I. (2012). Eniseiskoe kupechestvo v litsakh (XVIII nachalo $X X$ v.) [Yenisei merchants in persons (18 th - beginning of $20^{\text {th }}$ century)]. Novosibirsk, Publishing House of the SB RAS, $316 \mathrm{p}$.

Eniseiskie gubernskie vedomosti [Yenisei Provincial Gazette] (1863). 3; (1864), 27, 46; (1867), 10, 11; (1885), 44; (1886), 18; (1887), 22; (1912), 100.

Kasyanov Vasily Dmitrievich, archpriest (2012). Iz dnevnikov 1870-1897 gg.: v 2 kn. Avtor-sost. A.V. Brodneva [From the diaries of 1870-1897: in 2 books. Compiled by A.V. Brodneva]. Krasnoyarsk, Eastern Siberia. Book 1.770 p.

Komleva, E.V. (2009). Kobychevy [The Kobychevs]. In Istoricheskaia entsiklopediia Sibiri [Historical Encyclopaedia of Siberia], Vol. 2. Novosibirsk, 96.

Komleva, E.V. (2012). Kobychevy [The Kobychevs]. In Entsiklopedicheskii slovar' po istorii kupechestva i kommertsii Sibiri [Encyclopedic Dictionary of the History of Merchants and Commerce of Siberia], Vol. 1. Novosibirsk, GEO, 317.

Krivoshein, M.F. (1865). Eniseiskii okrug i ego zhizn' [Yenisei district and its life], Vol. 1-2. St. Petersburg, Edition of the ERGS, 650 p.

Kytmanov, A.I. (2016). Kratkaia letopis' Eniseiskogo uezda i Turukhanskogo kraia Eniseiskoi gubernii. 1594-1893 god/vstup. st. L.P. Berdnikova [Brief Chronicle of the Yenisei Uyezd and the Turukhansk Territory of the Yenisei Province. 1594-1893. Entry article by L.P. Berdnikov]. Krasnoyarsk.

Mininkov, N.A., Korenevsky, A.V., Ivanesko, A.E. (2010). Chelovek «vtorogo plana» v kontekste sovremennoi istoriografii: piat' let spustia [The "background" man in the context of modern historiography: five years later]. In V teni velikih: obrazy i sud'by: Sbornik nauch. statei. Seriia «Chelovek vtorogo plana v istorii» [In the shadow of the great: images and fates: Collection of scientific articles. Series "A Background Man in History"']. St. Petersburg, 19-28.

Stepanov, A.P. (1835). Eniseiskaia guberniia [Yenisei province], Part 1-2. St. Petersburg, Conrad Wingeber Pres, 364 p.

Turukhanskii Krai [Turukhansk Territory] (1896). In Vostochnoe obozrenie [Eastern Review], 116 (October 2). 3-4.

Shanin, V.Ya. (2011). Eniseiskaia letopis'. Khronologicheskii perechen' vazhneishikh dat i sobytij iz istorii Prieniseiskogo kraia. 1207-1834 gg [Yenisei Chronicle. A chronological list of the most important dates and events from the history of the Yenisei region. 1207-1834]. Krasnoyarsk, Trend, 448 p.

\section{List of abbreviations}

SAKK - State Archive of the Krasnoyarsk Territory;

YPG - Yenisei Provincial Gazette;

IRGS - Imperial Russian Geographical Society;

KRMLL - Krasnoyarsk Regional Museum of Local Lore;

RSHA - Russian State Historical Archive;

CC LRE - Complete collection of laws of the Russian Empire. 


\title{
Династия енисейских купцов Кобычевых: \\ становление, предпринимательство, участие в общественной жизни
}

\section{Е.В. Комлева}

Институт истории Сибирского отделения РАН

Российская Федерация, Новосибирск

\begin{abstract}
Аннотация. В статье рассматривается история одной из наиболее состоятельных и влиятельных купеческих династий Енисейска XIX в. - Кобычевых. Приводятся биографические данные (в том числе ранее неизвестные) о представителях разных поколений этого семейства. Характеризуется их хозяйственная деятельность, общественная служба, образ жизни. Реконструкция жизненного пути Кобычевых позволяет проследить закономерности, свойственные развитию всего сибирского купечества в целом и касающиеся условий и способов накопления первоначального капитала, сфер его последующего обращения, конфликтов и взаимодействия с региональной администрацией, влияния купцов на городскую среду. Анализ биографических сведений о Кобычевых, содержащихся в периодической печати и работах их современников, подчеркивает важное положение купечества в структуре сибирского городского социума и значительный вклад купцов в развитие экономики, общественной и культурной жизни региона.
\end{abstract}

Ключевые слова: сибирское купечество, Енисейск, Кобычевы, биография, хозяйственная деятельность, общественная служба, образ жизни.

Научные специальности: 07.00.00 - исторические науки, 24.00.00 - культурология. 